\title{
CRANB URY
}




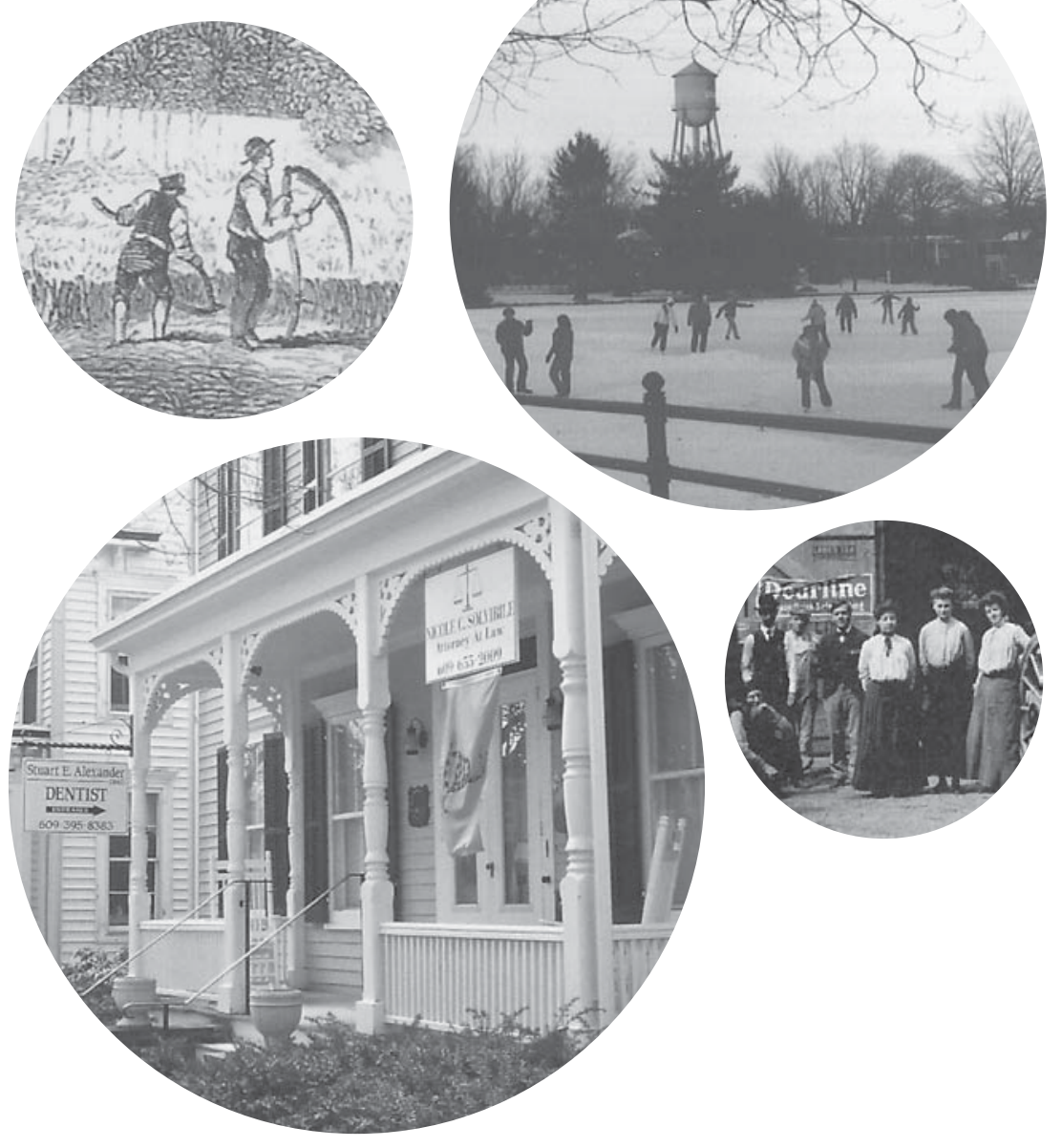




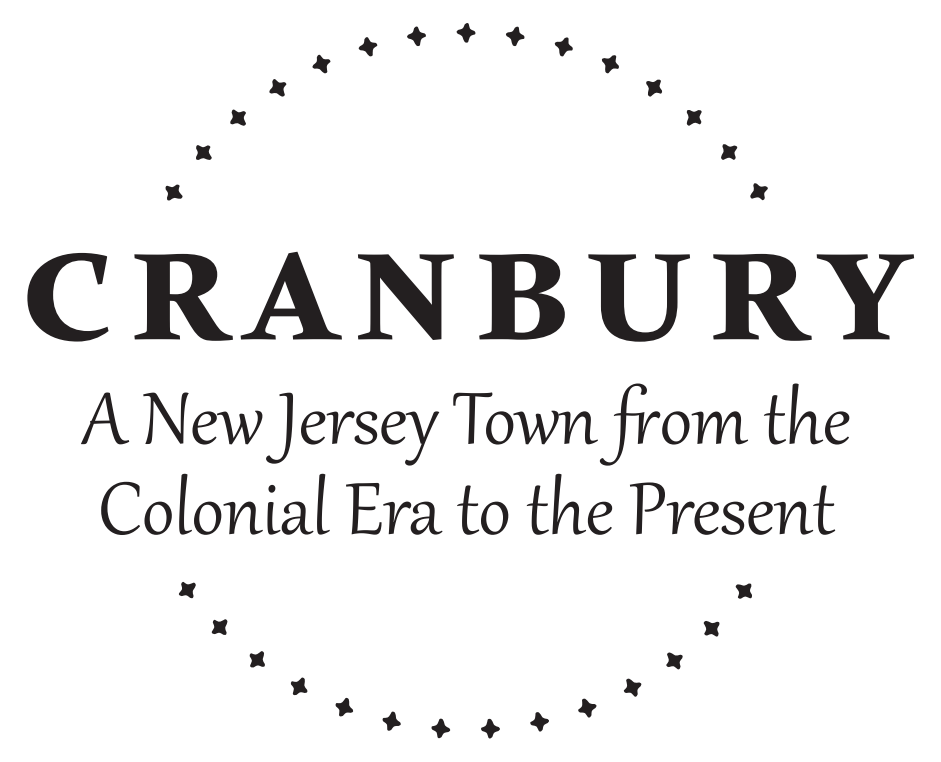

\author{
$\mathrm{JOH} \mathrm{N}$ \\ WH I T ECLAY \\ CHAMBERS
}

I I

Rivergate Books

AN IMPRINT OF RUTGERS UNIVERSITY PRESS

New Brunswick, New Jersey, and London 
Library of Congress Cataloging-in-Publication Data

Chambers, John Whiteclay.

Cranbury : a New Jersey town from the colonial era to the present / John Whiteclay Chambers II.

p. $\mathrm{cm}$.

Includes bibliographical references and index.

ISBN 978-0-8135-5287-3 (hardcover : alk. paper)

- ISBN 978-0-8135-5358-o (e-book)

I. Cranbury (N.J. : Township)-History. I. Title.

Fi44.C $78 \mathrm{C}_{47} 2012$

974.9'41-dc23 2011035599

A British Cataloging-in-Publication record for this book is available from the British Library.

A PROJECT OF CRANBURY LANDMARKS, INC.

Copyright (C) 2012 by Cranbury Landmarks, Inc.

All rights reserved

No part of this book may be reproduced or utilized in any form or by any means, electronic or mechanical, or by any information storage and retrieval system, without written permission from the publisher. Please contact Rutgers University Press, Ioo Joyce Kilmer Avenue, Piscataway, NJ 08854-8099. The only exception to this prohibition is "fair use" as defined by U.S. copyright law.

Visit our Web site: http://rutgerspress.rutgers.edu

Designed and typeset by Andrew Katz

Manufactured in the United States of America 
1 believe it is no coincidence that Cranbury has outstanding historic resources as well as a strong community spirit, sense of stability, congenial atmosphere, and civic commitment to meet the needs of all its citizens. In essence, the value of historic buildings is not just that they are attractive but that they give us a sense of continuity with the past and enhance all aspects of a community's life.

\section{SAMUEL N. STOKES}

a former regional director of the National Trust for Historic Preservation and the author of Saving America's Countryside 
